\title{
Processes Influencing Floral Initiation and Bloom: The Role of Phytohormones in a Conceptual Flowering Model
}

Thomas L. D avenport

\begin{abstract}
AdDITIONAL INDEX WORDS. reproductive physiology, temperate fruit, apple, tropical fruit, citrus, mango, lychee, floral induction

SUMmary. The reproductive phenologies of temperate fruit tree species are briefly introduced and compared to the reproductive phenologies of three tropical and subtropical fruit tree species. The impact of leaf and fruit development and the phytohormones they may produce on the reproductive or vegetative fate of bourse buds in apple spurs serves as the model to discuss temperate fruit flowering. In contrast, conceptual models of citrus (CitrusL.), mango (Mangifera indica L.), and lychee (Litchi chinensis Sonn.) flowering are described which propose physiological mechanisms for both flowering and vegetative flushing in trees grown in subtropical and tropical environments. Possible roles for auxin and cytokinins in shoot initiation and for gibberellins and a putative florigenic promoter in induction are discussed as they relate to the physiology of flowering and vegetative flushing of tropical species. Successful application of these conceptual flowering models through the use of growth regulators and other horticultural management techniques to control flowering of citrus, mango, and lychee is described.
\end{abstract}

lowering is the single most important event in the survival of angiosperms. Woody tree species in this phylum have adapted a variety of mechanisms to ensure the success of this event. Fruitbearing, arboreal species have been selected for cultivation primarily because of their palatable fruit characteristics and qualities that make them particularly attractive. They can be broadly categorized into two main groups, deciduous fruit tree species that grow in temperate climates and evergreen species that thrive in both tropical and subtropical climates. These two groups display phenologies that incorporate adaptations to each climate, including timing of flowering to avoid injurious conditions such as freezing winter temperatures in temperate regions and the desiccating conditions present during dry seasons in the tropics and subtropics.

U niversity of Florida, Tropical R esearch and E ducation C enter, 18905 SW 280 Street, H omestead, FL 33031; tldav@gnv.ifas.ufl.edu. 
It is important to note the salient features and differences between the phenologies of these two groups. Because the continental $U$ nited States is mostly located across a range of temperate latitudes, the majority of horticulturists reading this article are alreadyfamiliar with temperatefruit phenologies. L ess space will, therefore, be devoted to this topic. Areas of $\mathrm{H}$ awaii, southern California, Arizona, Texas, and Florida, however, are major production sites for fruit adapted to the tropics and/ or subtropics. M y familiarity with the phenologies and possiblemechanisms of flowering of tropical and subtropical fruit makes me better able to discuss them in more detail.

Deciduous fRUIT tRee ReProducTIVE PHENOLOGY IN TEMPERATE CLIMATES. Because growing seasons last no more than 6 to 8 monthsin temperatezones, and the time necessary from floral initiation to fruit maturity may last up to 1 year in these conditions, temperate fruit treeshave ad apted mechanismsto protect the reproductive and vegetative organs through cold winter periods. In general, floral buds initiate in mid to late summer, forming floral structures before the trees become dormant in preparation for winter. Pome fruit, such as apples (Malus pumila Mill.) and pears (Pyrus communis L.), initiate flowers predominantly in terminal buds of shoots and spurs. Stone fruit, such as plums (Prunus domestica L.), peaches (Prunus persica L.) and apricots (Prunus armeniaca L.), initiate flowers in lateral buds on current season shoots as well as older lateral spurs. A summary of flowering architectures and phenologies of these and other temperate tree crops can be found in Sedgley (1990) and Westwood (1993).

Perhaps the most extensive documented information on temperatetree fruit reproductive physiology can be found for apple (Greene, 1996). Anthesis of temperate tree flowers occurs in early spring. The majority of flowering and fruiting typically occurs in spurs of apple, but some cultivars produce a high percentage of flowers and fruit on longer terminal shoots or in lateral buds. The flowering cycle in spurs begins soon after the break of dormancy in spring before anthesis of floral buds that had formed the previous year. Development is initiated in the bourse bud located in the apex of vegetative spurs. This bud slowly initiates a series of nodes through the growing season starting with bud scales (typically 7 to 11 in number) followed by two to three transition leaves, three to six true leaves, and finally three bracts ( $\mathrm{MCL}$ aughlin and Greene, 1991). The number of each of these lateral organs varies with cultivar but is relatively constant in each regardless of rootstock (H irst and Ferree, 1995). Floral induction in the developing bourse bud typically coincides with the transition from true leaf to bract formation, which occursduring theinitial period of vegetative growth of the previousyear's bourse bud. N umerous factors, however, affect floral induction during this transition and can determine whether it is to remain vegetative or to become reproductive (Dennis, 1967; Greene, 1996).

The presence of small, developing fruit during the transition period is the dominant factor affecting the outcome of the bourse bud. If flowers, initiated during the previous season, set fruit on the spur during the current spring growth, then the bourse bud will, in most cultivars, remain vegetative the following year, giving riseto thestrong alternate bearing tendency typical of individual spurs. If, however, no fruit are present on the spur, then floral induction usually occurs; and thefloral buds begin differentiation forming individual floral structures before entering winter dormancy. Anthesis occurs during the following spring following a suitable number of winter chilling hoursto break bud dormancy (Greene, 1996).

A putative florigenic component appears to be translocated from current season spur leaves to promote flowering in bourse buds. Spur leaf removal (Ramirez and $\mathrm{H}$ oad, 1981), small leaf areas (H uet, 1972), and shading (Cain, 1971) all negatively impact floral induction in bourse buds. Cytokinins, which are present in substantial quantities in spur leaves (Greene, 1975), may participate as this florigenic component since exogenously applied cytokinins can replace the requirement for leaves in the formation of floral buds (Ramirez and $\mathrm{Hoad}$, 1981).

A potent floral inhibitor appears to be produced and transported from seed sof developing fruit to cause bourse buds to remain vegetative ( $C$ han and Cain, 1967). This inhibitor appears to be $\mathrm{GA}_{7}$ or closely associated with it (Tromp, 1992). Theratio of thesetwo components, i.e. cytokinins derived from leaves and gibberellins derived from developing fruit, may interact to determine the fate of bourse buds. This point is supported by observations that spurs bearing more than six leaves can overcome the inhibitory effects of the fruit on floral development in bourse buds (H uet, 1972), and the inhibitory impact of gibberellins can be overcome by the cytokinin, benzyladenine ( $\mathrm{MCL}$ aughlin and Greene, 1984).

Because of the alternate bearing tendency of individual spurs, whole trees, or orchards; de-synchronization of the on/ off cycle of spurs on trees has been a major goal of horticulturists of temperate tree fruit. Chemical thinning of fruit in on-years or application of gibberellin-synthesisinhibitorsearly enough to negate the impact of gibberellins on the developing bud are possible key elements in this strategy.

TROPICAL AND SUBTROPICAL FRUIT TREE REPRODUCTIVE PHENOLOGY. Citrus, mango, and lychee are species adapted to tropical and subtropical climates. The growth and development phenologies of these fruit trees differ substantially from those of temperate fruit trees. T ree phenologies and proposed mechanisms of flowering have been reviewed in detail for citrus ( $D$ avenport, 1990), mango (D avenport and N uñez-Elisea, 1997), and lychee ( $M$ enzel, 1983, 1984). The flowering phenologies of each of these species are remarkably similar despitethe vastly different morphologies. These species thrive and reproduce in tropical as well as in subtropical climates, and their tolerance to freezing temperatures defines the limits of subtropical adaptability in higher latitudes. The focus of published information on flowering of these three species has varied, but the similarities in responses to environmental cues suggest that many of the findings of one species may be applicable to the others.

Individual stems of these three species of tropical fruit trees are dormant most of the time. G rowth occurs asperiodic, ephemeral flushes of shoots emerging from apical or lateral resting buds before returning to a quiescent state. Stems here are defined as branch tips that are in rest, whereas shoots refer to actively growing branch tipsor laterals regardless of type of growth, 


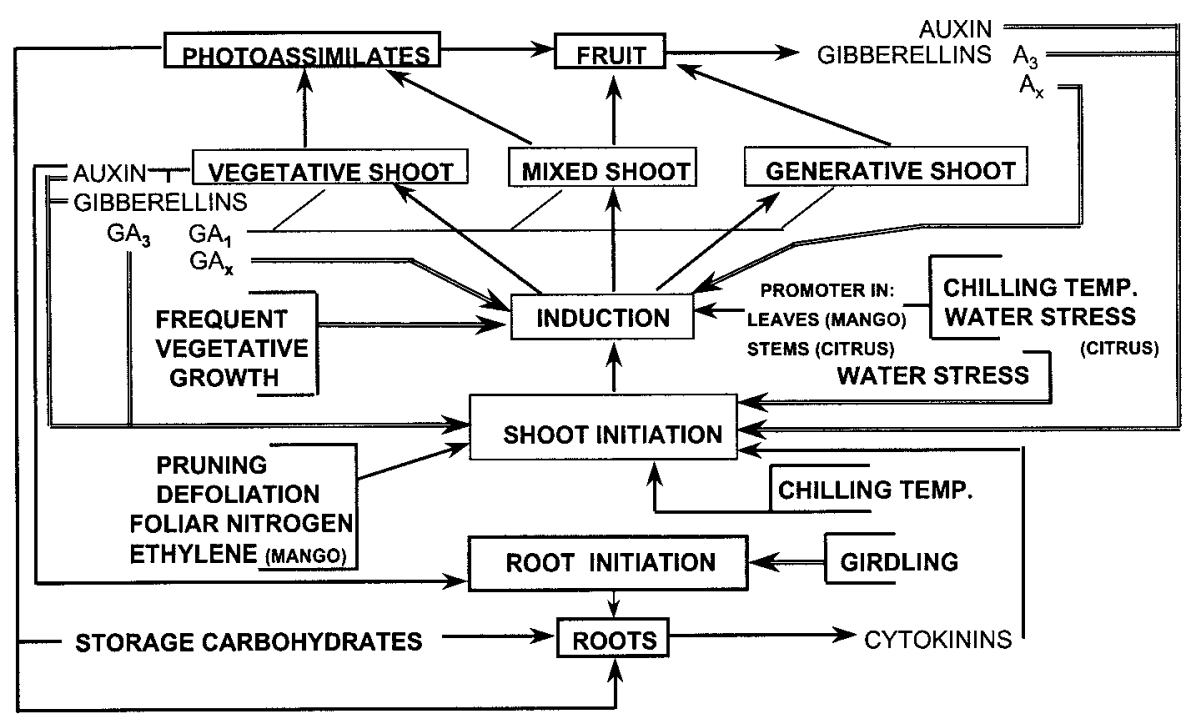

Fig. 1. Conceptual flowering model of citrus, mango, and lychee. Themodel summarizestheproposed rolesfor variousphytohormonesin initiation of shootgrowth and in defining the vegetativeor reproductiveoutcomeof thatgrowth (induction). Singlelinesin theschemearepromotiveand double linesareinhibitory.

i.e. vegetative or reproductive. Flushes refer to growth occurring in numerous shoots, usually in sections of tree canopy or throughout the entire tree. Periods of stem dormancy are short in young plants but can last more than 8 months between flushing episodes in mature trees. The three primary types of shoots that typically develop from dormant stems are vegetative (leaves only), generative (determinate inflorescences or panicles), or mixed (composed of both leaves and lateral inflorescences inserted at nodes). Vegetative flushes of growth typically occur one to several times per year on individual stems. Thefrequencies of flushes that occur annually depend upon cultivar, size of the tree, and growing conditions (especially as related to nitrogen and water availability). R eproductive flushes generally occur after extended periods of stem rest in the low-latitudetropicsor immediately following periods of cool night temperatures in the higher latitude tropics and subtropics. Flowering normally occurs in mango, lychee, and limes (Citrus latifolia Tan.) any time from January through $\mathrm{M}$ arch in the $\mathrm{N}$ orthern $\mathrm{H}$ emisphere and from J uly to September in the Southern H emisphere. Sweet orange and other subtropical citrus usually flower one to two months later depending on the length of cool peri- ods and the intensity of chilling night temperatures in the higher latitudes where they are grown. Variations in flowering patterns can be found in all cultivars among species depending on their age and whether they are planted in dry or humid tropics or in subtropical regions. A conceptual model depicting possible mechanisms in directing vegetativeand reproductivegrowth of these tropical and subtropical species is shown in Fig. 1.

Two distinctly separate events must happen for flowering or vegetative growth to occur in these species. The resting bud must first initiate growth. I nitiation is referred to here as the onset of rapid shoot development (bud break) regardless of the type of shoot evoked. Coincident with shoot initiation, induction occurs based on the conditions present at the time of initiation. Induction here refers to the temporary commitment of buds to evoke a particular shoot type, i.e., vegetative shoot (vegetative induction), generative shoot (floral induction) or mixed shoot (combined vegetativefloral induction). This concept differs from the definitions of initiation and induction developed in herbaceous plant flowering models. I n herbaceous plants, induction causes mother cells in apical meristems of growing budsto shift from producing transcripts responsible for organizing and developing vegetative structures to production of those responsible for development of reproductive organs (Bernier, 1988; Bernier et al., 1993; Kinet, 1993). I nitiation is then the first discernible expression of those new transcripts. Although conditions suitable for floral induction may be present before shoot initiation in tropical fruit trees, determination of the inductive condition in buds is not made until shoot initiation occurs (Batten and M cC onchie 1995; D avenport, 1990; Davenport and N uñez-Elisea, 1997; N uñez-Elisea et al., 1993, 1996).

Shoot initiation and floral/ vegetative induction events are regulated by different signals and, therefore, can be manipulated by different stimuli. For example, removing theapical leaves or tip pruning physiologically mature stems of either mango or citrus soon stimulates initiation of bud break in apical or lateral buds, respectively (N uñez-Elisea et al., 1991; Southwick and D avenport, 1986, 1987). When a plant of any of these species is exposed to warm temperatures $\left[30^{\circ} \mathrm{C}\left(86^{\circ} \mathrm{F}\right)\right.$ day/ $25^{\circ} \mathrm{C}\left(77^{\circ} \mathrm{F}\right)$ night] at the time of shoot initiation, the resulting shoot growth is purely vegetative. If it is instead maintained in cool conditions [ $18^{\circ} \mathrm{C}\left(64^{\circ} \mathrm{F}\right)$ day/ $10^{\circ} \mathrm{C}\left(50^{\circ} \mathrm{F}\right)$ night], it produces generative shoots. If placed in either of the two temperatures without clipping or tip pruning, initiation of bud break may take several monthsto occur but the outcome is the same ( $D$ aven port, 1990; $D$ avenport and Nuñez-Elisea, 1997). Vegetative or generative shoots are, thus, evoked according to conditionspresent at the time of initiation (Batten and M cC onchie, 1995; N uñez-Elisea and Davenport, 1991a; N uñez-Elisea et al., 1991, 1996; Southwick and D avenport, 1986, 1987). Stems do not retain their floral inductive potential when removed from the cool environment. I transferred from cool to warm temperatures before initiation of bud break, then the new shoot growth is vegetative instead of reproductive and vice versa (D avenport, 1990; N uñezElisea et al., 1996). This point was further reinforced by observationsthat vegetative (V) or generative ( $G$ ) shoot types can be reversed in lychee and mango during shoot morphogenesis. Transition shoots $(V>G$ or $G>V$ ) were evoked when containerized trees were transferred from warm-to-cool or coolto-warm temperatures, respectively, during early bud development (Batten and M cConchie, 1995; N uñez-Elisea et al., 1996).

The cyclic initiation of shoots on dormant stems, whether vegetative or reproductive, is common to many tropical and subtropical fruit species (D avenport, 1986, 1990; M enzel, 1983, 1984). Developing vegetative 
shoots are rich sources of auxins and gibberellins, which may beinvolved in regulating the timing of subsequent shoot initiation. Auxins are actively transported basipetally to roots from production sites in developing shoots (Cane and Wilkins, 1970; Goldsmith, 1968), and they are known to stimulateadventitiousroot growth in mango and other crops(H assig, 1974; N uñezElisea et al., 1992). Elevated levels of auxin synthesis in periodically flushing shoots are likely to form a periodic pulse of concentrated auxin, which moves basipetally to the roots. This putative pulse of elevated auxin arriving at the roots may stimulate initiation of new root flushesfollowing each vegetative flush. Alternation of root and shoot growth has been observed in citrus (Bevington and Castle; 1986) and mango (C ull, 1991; T.L. D avenport, unpublished results).

$\mathrm{N}$ ew roots that develop following growth stimulation are known to be a primary source of cytokinins (I tai et al., 1973). Cytokinins are passively transported to shoots via the xylem sap. They have been demonstrated to accumulate in resting stem buds and correlate with shoot initiation of citrus ( $\mathrm{H}$ endry et al., 1982; Saidha et al., 1983). Exogenously applied cytokininsstimulate shoot initiation of citrus ( $N$ auer and Boswell, 1981) and mango (Chen, 1985; N uñez-Elisea et al., 1990). It is well established, however, that auxin inhibits shoot initiation and enforces apical dominance by preventing axillarybudsfrom initiating growth (D avies, 1995). Based on research in other species, it is likely that leaf auxin production and petiolar auxin transport capacity declines as leaves age during stem dormancy ( $D$ aven port et al., 1980; Veen and Jacobs, 1969). These observations suggest that auxins (inhibitory) and cytokinins (promotive) may be interactively involved in periodic bud break (Fig. 2). Shoot initiation may beregulated by a critical balance of these two and possibly a third phytohormone (gibberellin $\mathrm{A}_{3}$ acting indirectly) rather than the absolute concentration of any one of these compounds (Cline, 1997; Cline et al., 1997). During dormant periods, the supply of auxin from leaves to buds of mango decreases with age (Chen, 1987). In contrast, cytokinin levels in buds have been reported to increase over time (Chen, 1987). Perhaps at some point, when a critical cytokinin/ auxin ratio is reached, the bud is initiated, thus, resetting theinitiation cycle.

Fruit are rich sources of auxin and gibberellins, which may contribute to the strong inhibition of bud break commonly observed on fruit-bearing stems. The longer fruit remain attached, the longer the post-harvest inhibition of shoot initiation on that stem may last (Davenport, 1990; Kulkarni, 1991; Kulkarni and Rameshwar, 1989).

Foliar-applied nitrogen can also impact shoot initiation. For example, urea enhances initiation of citrus flowering (Ali and Lovatt, 1994; Davenport, 1990). M oreover, foliar-applied potassium, ammonium, or calcium nitrate stimulates shoot initiation of mango in the low-latitude tropics and is widely used there to stimulate flowering (Bondad and L insangan, 1979; N uñez-Elisea, 1985; N uñez-Eliseaand Caldeira, 1988). To be successful in stimulating flowering, however, the nitrate salt must be applied after the resting stems of mango have reached sufficient age to overcome any inhibitory influence they may have on the flowering response.

Water stress replaces chilling as the primary trigger for citrus floral induction in areas of the tropics where temperatures are al ways moderate but which have distinct rainy and dry seasons (C assin et al., 1969; R euther and Rios-C astaño, 1969)). The direct impact of water stress on flowering of citrus has been covered in detail elsewhere (D avenport, 1990). Whereas water stress has been thought to induce flowering of mango and lychee, there is no conclusive evidence that water stress is directly involved in inductive processes as has been found in citrus (M enzel, 1983; N uñez-Elisea and Davenport, 1994). M oderately low water potentials delay shoot initiation through reduced turgor, thus contributing to extending the age of stems and reducing the levels of a putative floral inhibitor (vegetative promoter) that is proposed to reside in the leaves (Kulkarni, 1991; N uñezElisea and D avenport, 1994).

Exogenously applied gibberellic acid $\left(\mathrm{GA}_{3}\right)$ inhibits flowering of both citrus ( $D$ aven port, 1990; G uardiola et al., 1982) and mango (N uñez-Elisea and $D$ avenport, 1991b). It is yet not clear whether this phytohormone impacts floral induction in citrus or whether it only impacts shoot initiation as seems to be the case for mango ( $N$ uñez-Elisea and D avenport, 1998; Tomer, 1984). The normal presence of this phytohormone in leaves, buds, and fruit of mango ( $C$ hen, 1987; $D$ avenport et al., 2000) suggests that $\mathrm{GA}_{3}$ may interact with auxin to inhibit shoot initiation. $\mathrm{GA}_{3}$ was not detected in citrus leaves (Poling and $M$ aier, 1988), which suggests that it may be metabolized to another compound to influence its impact on flowering when exogenously applied. O bservations of early flowering in mango trees treated with paclobutrazol is likely a response to lowered $\mathrm{GA}_{3}$ levels, thus lowering the overall level of inhibition of shoot initiation ( $D$ avenport and $\mathrm{N}$ uñezElisea, 1990; Voon et al., 1991).

Evidence indicates that the induction switch is governed in all of these tropical species by the interaction of a putativefloral promoter, which is up-regulated during exposure to

Fig. 2. Possibleinteraction of phytohormonesregulatingshootinitiation. C ytokininsfrom rootsareproposed to serveasa promoter and auxin from leavesand fruitasan inhibitor of shoot initiation. Conditionsconduciveto alow ratio of promoter to inhibitor would result in continued rest of stem buds whereasaratio aboveathreshold level would beconduciveto initiation of new shootsregardless of shoottype. 
GENERATIVE SHOOT

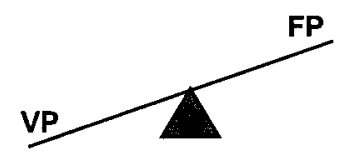

VEGETATIVE SHOOT

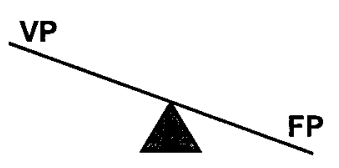

MIXED SHOOT

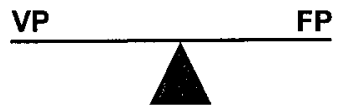

vital plant organs, including fruit, when present. Further experimental results are needed to clarify the role of carbohydrates in shoot initiation or induction.

This model is consistent with growth and development patternstaking place in citrus, mango, and lychee trees growing in the both the tropics and subtropics throughout the world. It, however, remainsconceptual, especially with regard to the regulatory details. Current and future research efforts will continue to revise and refinethe model by testing the validity of the hypotheses embedded in it. It is hoped that a realistic understanding of the mechanisms of flowering and vegetative growth in tropical fruit trees will result.

Citrus, mango and lychee growers have been able to improve production and manipulatethetiming of their crops through the application of concepts summarized here. Citrus growers in the subtropics are realizing a greater amount of flowering and yield after application of urea (Ali and L ovatt, 1994), and those in the tropics use water stressto stimulateflowering when desired (Cassin et al., 1969). M ango growers can now stimulate flowering and subsequent cropping at any time of the year in the N orthern or Southern $\mathrm{H}$ emisphere tropics. They do this using mild water stress or low nitrogen fertilization to reduce leaf nitrogen levels and discourage flushes for at least 6 months before stimulation of a flowering flush using foliar nitrate spray. M ore commonly, growers now apply paclobutrazol to substitute for the age requirement provided by mild water stress or low nitrogen to obtain flowering on younger stems (Kulkarni and $\mathrm{H}$ amilton, 1996; $\mathrm{N}$ artvaranant et al., 1999). L ychee growers are achieving more reliable flowering, especially in low-production cultivarsby discouraging fall vegetative flushes, thus insuring adequate age of the stems when the cool night temperatures occur in winter (M enzel, 1983).

In conclusion, both the temperate and tropical and subtropical fruit tree species demonstrate flowering phenologies that are well adapted to the environments in which they originated. Specific roles for phytohormones have been implicated in both groups to explain the mechanisms of flowering and timing of the event. Both groupsappear to utilize a flower- 
ing promoter, which in some cases in both groupshasbeen demonstrated to be produced in leaves and translocated to buds. Cytokinins have been associated with floral induction in deciduous fruit crops whereas this class of phytohormone has been implicated in shoot initiation in resting buds of tropical species. Components (perhaps $\mathrm{GA}_{4 / 7}$ ) translocated from seeds of apple appear to function as a vegetative promoter. Although $\mathrm{GA}_{4 / 7}$ is not present in mango, $\mathrm{GA}_{3}$ from seeds and leaves may interact with auxin to participate in inhibition of shoot initiation (D avenport et al., 2000), and an unidentified gibberellin in leaves may act as the vegetative promoter ( $D$ avenport and $\mathrm{N}$ uñez-Elisea, 1997). The ratio of the putative floral and vegetative promoters appears to regulate the reproductiveor vegetativefate of both thebourse buds in temperate fruit trees and the buds of tropical plants as they initiate growth.

It is plausible to consider that the floral promoter in apple is dependant upon cool temperatures of spring to enable floral induction at the appropriate time, as is the case of tropical plants. If this were the case, then the similarity of roles for the variousclasses of phytohormones warrants further comparisons between these two diverse groups of plants. Future research may be able to resolve this point.

\section{Literature cited}

Ali, A.G. and C.J. L ovatt. 1994. Winter application of low-biuret ureato thefoliage of 'Washington' navel orange increased yield. J. Amer. Soc. H ort. Sci. 119:1144-1150.

Batten, D.J. and C.A. M cC onchie. 1995. Floral induction in growing buds of lychee (Litchi chinensis) and mango (M angifera indica). Austral. J. Plant Physiol. 22:783-791.

Bernier, G. 1988. The control of floral evocation and morphogenesis. Annu. Rev. Plant Physiol. 39:175-219.

Bernier, G., A. H avelange, C. H oussa, A. Petitjean, and P. L ejeune. 1993. Physiological signals that induce flowering. Plant Cell 5:1147-1155.

Bevington, K.B. and W.S. Castle. 1986. Annual root growth pattern of young citrus trees in relation to shoot growth, soil temperature, and soil water content. J. Amer. Soc. H ort. Sci. 110:840-845.

Bondad, N .D . and E. Linsangan. 1979. Flowering in mango induced with potassium nitrate. $\mathrm{H}$ ortScience 14:527-528.

Cain, J.C. 1971. Effect of mechanical pruning of apple hedgerows with a slotted saw on light penetration and fruiting. J. Amer. Soc. H ort. Sci. 96:664-667.

Cane, A.R. and M .B. Wilkins. 1970. Auxin transport in roots. J. Expt. Bot. 21:212-218.

Cassin, J., B. Bourdeaut, F. Fougue, V. Furin, J.P. Gaillard, J. Le Bourdelles, C. M ontigut, and C. M onevil. 1969. Theinfluence of climateupon the blooming of citrus in tropical areas. Proc. 1st Intl. Citrus Symp. 1:315-323.

Chan, B.G. and J.C. Cain. 1967. The effects of seed formation in subsequent flowering in apple. Proc. Amer. Soc. H ort. Sci. 91:63-68.

Chen, W.S. 1985. Flower induction in mango (Mangifera indica L.) with plant growth substances. Proc. N atl. Sci. Council Part B, Life Sci. Taipei, Rep. China 9:9-12.

Chen, W.S. 1987. Endogenous growth substancesin relation to shoot growth and flower bud development of mango. J. Amer. Soc. H ort. Sci. 112:360-363.

Cline, M.G. 1997. Concepts and terminology of apical dominance. Amer. J. Bot. 84:1064-1069.

Cline, M.G., T. Wessel, and H . I wamura. 1997. Cytokinin/ auxin control of apical dominance in I pomoea nil. Plant Cell Physiol. 38:659-667.

Cull, B.W. 1991. Mango crop management. Acta H ort. 291:154-173.

D avenport, T.L. 1986. Avocado flowering. H ort Rev. 8:257-289.

Davenport, T.L. 1990. Citrus flowering. H ort. Rev. 12:349-408.

D avenport, T.L., P.W. M organ, and W.R. Jordan. 1980. Reduction of auxin transport capacity with age and internal water deficits in cotton petioles. Plant Physiol. 65:1023-1025.

Davenport, T.L. and R. Nuñez-Elisea. 1990. Ethylene and other endogenous factors possibly involved in mango flowering. Acta $\mathrm{H}$ ort. 275:441-448.

Davenport, T.L. and R. Nuñez-Elisea. 1997. Reproductive physiology, p. 69-146. In: R.E. Litz (ed.). M ango botany, production and use. CAB Intl., Wallingford Oxon, U.K.

D avenport, T.L., Pearce, D.W., Rood, S.B. 2000 Correlation of endogenous gibberellic acid with initiation of mango shoot growth. J. Plant G rowth Reg. (in press).

Davies, P.J. (ed.). 1995. Plant hormonesPhysiology, biochemistry and molecular biology. Kluwer, Boston.

D ennis, F.G. 1967. The physiology of flowering and fruit set in fruit trees. Proc. O re. $\mathrm{H}$ ort. Soc. 77:33-43.

Goldsmith, M.H.M. 1968. The transport of auxin. Annu. Rev. Plant Physiol. 19:347-360.

Greene, D.W. 1975. Cytokinin activity in the xylem sap and extracts of M M 106 apple rootstocks. H ortScience 10:73-74.

Greene, D.W. 1996. Flower development, $p$. 91-98. In: M. M arl, P. Andrew, G. Lang, and K. M ullinex (eds.). Tree fruit physiology: Growth and development. Good Fruit Grower, Yakima, Wash.

Guardiola, J.L., C. Monerri, and M. Agusti. 1982. The inhibitory effect of gibberellic acid on flowering in Citrus. Physiol. Plant. 55:136-142.

H assig, B.E. 1974. O rigins of adventitious roots. N.Z. J. For. Sci. 4:229-310.

H endry, N .S., J. van Staden, and P. Allan, 1982. Cytokinins in citrus. II. Fluctuations during growth in juvenile and adult plants. Scientia H ort. 17:247-256.

H irst, P.M . and D.C. Ferree, 1995. Rootstock effects on 'D elicious' apple. I. Bud development. J. Amer. Soc. H ort. Sci. 120:1010-1017.

H uet, J. 1972. Etude des effeis levieles et des fruits sur l'induction florale brachyblastes du poirier. Physiol. Vegetale 10:529-545.

Itai, C., A. Ben-Zioni, and L. Ordin. 1973. Correlative changes in endogenous hormone levels and shoot growth induced by short heat treatments to the root. Physiol. Plant. 29:355360.

Kinet, J.M . 1993. Environmental, chemical, and genetic control of flowering. $\mathrm{H}$ ort. Rev. 15:279334.

Kulkarni, V.J. 1986. Graft-induced off-season flowering and fruiting in the mango ( $M$ angifera indica L.). J. H ort. Sci. 61:141-145.

Kulkarni, V.J. 1988. Further studies on graftinduced off-season flowering and fruiting in mango (Mangifera indica L.). J. Hort. Sci. 63:361-367.

Kulkarni, V.J. 1991. Physiology of flowering in mango studied by grafting. Acta H ort. 291:95104.

Kulkarni, V. and D. H amilton. 1996. An integrated approach towards improving mango productivity. Acta H ort. 455:84-91.

Kulkarni, V.J . and A. Rameshwar. 1989. Effect of deblossoming and defruiting on off-season flowering and fruiting in mango ( $M$ angifera indica L.). Scientia H ort. 39:143-148.

M CL aughlin, J.M . and D.W. Greene. 1984. Effect of $\mathrm{BA}, \mathrm{GA}_{4+7}$ and daminozide on fruit set, fruit quality, vegetative growth, flower initiation, and flower quality in Golden Delicious apple. J. Amer. Soc. H ort. Sci. 109:34-39.

M CL aughlin, J.M . and D.W. G reene. 1991. Fruit and hormones influence flowering of apple. I. Effect of cultivar. J. Amer. Soc. H ort. Sci. $116: 446-449$.

M enzel, C.M . 1983. The control of floral initiation in lychee: a review. Scientia H ort. 21:201215.

M enzel, C.M . 1984. The pattern and control of 
reproductive development in lychee: a review. Scientia H ort. 22:333-345.

N artvaranant, P., S. Subhadrabandhu, and P. Tongumpai. 1999. Practical aspect in producing off-season mango in Thailand. Acta H ort. (in press).

N auer, E.M . and S.B. Boswell. 1981. Stimulating growth of quiescent citrus buds with 6benzylamino purine. H ortScience 16:162-163.

N uñez-Elisea, R. 1985. Flowering and fruit set of a monoembryonic and polyembryonic mango as influenced by potassium nitrate sprays and shoot decapitation. Proc. Fla. StateH ort. Soc. 98:179183.

N uñez-Elisea R. and M.L. Caldeira. 1988. Induction of flowering in mango ( $M$ angifera indica) with ammonium nitratesprays. $\mathrm{H}$ ortScience 23:833.

N uñez-Elisea, R., M .L. Caldeira, and T.L. D avenport. 1990. Thidiazuron effects on growth initiation and expression in mango ( $M$ angifera indica L.). H ortScience 25:1167 (abstr.).

N uñez-Elisea, R., M.L. Caldeira, W. Ferreira, and T.L. D avenport. 1992. Adventitiousrooting of 'T ommy Atkins' mango air layersinduced with naphthaleneacetic acid. H ortScience 27:926.

N uñez-Elisea, R. and T.L. Davenport. 1989. Expression of an endogenous flowering promoter in mango ( $M$ angifera indica). Proc. 16th Annu. M eet. Plant Growth Reg. Soc. Amer. p. 245-247.

N uñez-Elisea, R. and T.L. D avenport. 1991a. Effect of duration of low temperature treatment on flowering of containerized 'Tommy Atkins' mango. Proc. 18th Annu. M eet. Plant Growth Reg. Soc. Amer. p. 39-41.

N uñez-Elisea, R. and T.L. D avenport. 1991b.
Flowering of 'Keitt' mango in response to deblossoming and gibberellic acid. Proc. Fla. State H ort. Soc. 104:41-43.

N uñez-Elisea, R. and T.L. Davenport. 1992. Requirement for mature leaves during floral induction and floral transition in developing shoots of mango. Acta H ort. 296: 33-37.

N uñez-Elisea, R. and T.L. Davenport. 1994. Flowering of mango trees in containers as influenced by seasonal temperature and water stress. Scientia H ort. 58:57-66.

N uñez-Elisea, R. and T.L. D avenport. 1995. Effect of leaf age, duration of cool temperature treatment, and photoperiod on bud dormancy release and floral initiation in mango. Scientia H ort. 62:63-73.

N unez-Elisea, R. and T.L. D avenport. 1998. Gibberellin and temperatureeffectson dormancy release and shoot morphogenesis of mango (M angifera indica L.). Scientia H ort. 77:11-21.

N uñez-Elisea, R., T.L. Davenport, and M.L. Caldeira. 1991. An experimental system to study mango flowering using containerized treespropagated by air-layering. Proc. Fla. State H ort. Soc. 104:39-41.

N uñez-Elisea, R., T.L. Davenport, and M.L Caldeira. 1993. Bud initiation and morphogenesis in 'Tommy Atkins' mango as affected by temperatureand triazolegrowth retardants. Acta H ort. 341:192-198.

N uñez-Elisea, R., T.L. Davenport, and M.L. Caldeira. 1996. Control of bud morphogenesis in mango (Mangifera indica L.) by girdling, defoliation and temperaturemodification. J. $\mathrm{H}$ ort. Sci. 71:25-40.

Poling, S.M . and V.P. M aier. 1988. I dentification of gibberellinsin navel oranges. Plant Physiol. 88:639-670.
Ramirez, H. and G.V. H oad. 1981. Effect of growth substanceson fruit-bud initiation in apple. Acta H ort. 120:131-136.

Reuther, W. and D. Rios-Castaño. 1969. Comparison of growth, maturation and composition of citrusfruitsin subtropical California and tropical Columbia, p. 277-300. In: H.D. Chapman (ed.). Proc. 1st Intl. CitrusSymp. U niv. of Calif., Riverside.

Saidha, T., E.E. Goldschmidt, and S.P. M onselise 1983. Endogenousgrowth regulatorsin tracheal sap of citrus. H ortScience 18:231-232.

Sedgley, M. 1990. Flowering of deciduous perennial fruit crops. H ort. Rev. 12:223-264.

Southwick, S.M. and T.L. Davenport. 1986. Characterization of water stressand low temperature effects on flower induction in citrus. Plant Physiol. 81:26-29.

Southwick, S.M. and T.L. Davenport. 1987 M odification of the water stress-induced floral response in 'T ahiti' lime. J. Amer. Soc. H ort. Sci. 112(2):231-236.

Tomer, E. 1984. I nhibition of flowering in mango by gibberellic acid. Scientia H ort. 24:299-303.

Tromp, J. 1992. Flower bud formation in apple as affected by various gibberellins. J. H ort. Sci. 57:277-282.

Veen, H . and W.P. Jacobs. 1969. T ransport and metabolism of indole-3-acetic acid in coleus petiole segments of increasing age. Plant Physiology 44:1157-1162.

Voon, C.H ., C. Pitakpaivan, and S.J. T an. 1991. $\mathrm{M}$ ango cropping manipulation with Cultar. Acta H ort. 291:219-228.

Westwood, M.N. 1993. Temperate-zone pomology: Physiology and culture. 3rd ed. Timber Press, Portland. 